\title{
Марина Будзар
}

\section{ICТОРІЯ КИЄВА В ЕGО-ДОКУМЕНТАХ: ЛИСТ Г.П. ҐАЛАҐАНА ДО О.В. КОЧУБЕЯ 1857 р.}

\author{
У статті наводиться лист Г.П. Галагана до дядька його дружини О.В. Кочубея, у якому описано \\ події приїзу до Києва Олександра II 1857 р.
}

Ключові слова: Григорій Павлович Галаган, Олександр Васильович Кочубей, Київ, 1857 p.

\begin{abstract}
Сучасна історична урбаністика послуговується понятійним інструментарієм, притаманним усім гуманітарним студіям. Проте використання джерельного матеріалу, зокрема епістолярної спадщини відповідної доби, $€$ однією з головних потреб фахівців у царині історико-культурних досліджень, котрі вивчають українські міста. Не в останню чергу це твердження $є$ слушним для українського епістолярію XIX ст., доби, коли, за правдивим висловом С. Абросимової, приватне листування «стає своєрідною “віддушиною”, самовизначенням особистості, формою наукових, культурних, літературних та суспільних бесід, обговорення актуальних проблем громадсько-політичного і культурного життя...»1.

Нашу увагу привернув документ 3 досить великого масиву листування Григорія Павловича Галагана (1819-1888), нащадка знаного в істоpiї Гетьманщини козацько-старшинського роду, представники якого (від Гната Галагана (?-1744), прапрадіда автора листа, до Павла Галагана (1792-1834), його батька) успішно пройшли процес інкорпорації до лав імперського дворянства. Оприлюднення листування Г.П. Галагана, одного 3 найзаможніших землевласників Лівобережної України (до 40 тисяч десятин землі у Полтавській та Чернігівській губерніях), впливового суспільно-політичного діяча на всіх рівнях соціального життя, котрий розпочав суспільну діяльність Борзнянським повітовим маршалком (1848-1851), а завершив членом Державної Ради Російської імперії (1882-1888), інтелектуала, близького до московського гуртка слов'янофілів і водночас до київської «Старої Громади», видається нам доречним і необхідним.
\end{abstract}

Передусім нагальною залишається проблема дослідження української еліти у межах «імперського» XIX ст. не лише з позиції іï ролі

\footnotetext{
1 Абросимова С.В. Епістолярні джерела в їх історичному побутуванні та дослідницькому ареалі // Дніпропетровський історико-археографічний збірник. Дніпропетровськ, 2009. - Вип. 3. - С. 73.
}

у суспільно-політичному та культурно-духовному процесах, але й у багатоаспектних проявах повсякденно-господарського, родинно-побутового життя, презентаціях світоглядних пріоритетів, внутрішнього світу поміщика, дворянина. Не менш важливим завданням $є$ реконструкція історії Києва за безпосередніми враженнями його мешканців, зафіксованими у приватному епістолярії.

Значимість інформативного потенціалу листів Г.П. Галагана для змалювання епізодів з життя Києва була відзначена ще А.І. Степовичем² ${ }^{2}$ Серед сучасних дослідників Т.Ф. Литвинова наголосила на тому, що джерельна спадщина цієї особи не тільки до кінця не вичерпана, але й не введена повністю до наукового обігу. Вона також вказала на те, що для «дослідження суспільної ситуації періоду «гласності» досить інформативними $€ 10$ з 12 листів Григорія Павловича за 18571860 рр.» ${ }^{3}$. Дослідниця має на увазі добірку листів, що зберігаються у фонді III Інституту рукопису НБУВ під номерами 11 092-11 101 та помилково позначені як «листи Г.П. Галагана до дядечка П.Г. Галаґана». Насправді ці листи адресовані не Петру Григоровичу Галагану (1792-1855), рідному дядькові автора, а Олександру Васильовичу Кочубею (1788-1866), дядькові його дружини, Катерини Василівни Галаган, уродженій Кочубей (1826-1896). Саме перший із вказаних листів, від 16 листопада 1857 р., пропонується для друку. На час написання листа Г.П. Галаган вже мав у Києві, на розі вулиць Прорізної та Хрещатику будинок, придбаний 1856 р. у князя О.К. Любомирського ${ }^{4}$ та перебудований за проектом архітектора I.В. Штрома (1823-1887). Так, ставши остаточно киянином (пізніше взимку родина Галаганів

2 Про київське життя 1849 р. [Подав А. Степович] // Україна. - 1925. — № 6. - С. 109-110.

3 Литвинова Т.Ф. «Поміщицька правда»: дворянство Лівобережної України та селянське питання наприкінці XVIII - у першій половині XIX століття (ідеологічний аспект). - Д. : Ліра, 2011. - С. 624.

4 Центральний державний історичний архів України, м. Київ. - Ф. 486. - Оп. 5. - Спр. 319. - Арк. 86-88. 
найчастіше мешкала у Києві), він був обізнаний в основних подіях, що відбувалися у місті.

Наведений нижче лист, як і всі еgо-документи, $\epsilon$ поліфукційним джерелом, окрім центрального епізоду оповіді - візиту Олександра II до Києва восени 1857 р. - його зміст зачіпає низку питань суспільно-політичних (початок процесу «емансипації» - реформи зі скасування кріпосного права) та приватно-родинних (господарчі проекти Г.П. Галагана, передусім відкриття цукрового заводу у складі Ічнянського маєтку, сімейні справи). Характерною ознакою документа $€$ його інтимно-дружня інтонація, яку відмітив ще А.I. Степович, готуючи до друку наприкінці 1920-х рр. 10 листів Г.П. Галагана до дядечка О.В. Кочубея: «листи сі писані, так сказати, інтимно, не для друку, автор писав їх своєму дядькові 3 щирим серцем...»5. Такий тон листа пояснюється, вочевидь, близькими стосунками автора із сімейством своєї дружини, представниками однієї з гілок знаного в історії України роду Кочубеїв, спорідненістю з яким він, безумовно, пишався, зауваживши в біографічному нарисі «Род Галаганов»: «эта фамилия чисто малороссийская и по заслугам многих из своих членов приобрела права гражданства, вместе с правом общего уважения в Малороссии...» ${ }^{6}$. Брати померлого за рік до весілля дочки Василя Васильовича Кочубея (1784-1846), старшого в роді, таємного радника, учасника військових кампаній проти

5 Інститут рукопису Національної бібліотеки України імені В.І. Вернадського. - Ф. 179. - Оп. 1. - Спр. 131. Арк. 1.

6 [Галаган Г.П.] Род Галаганов // 25-летие Коллегии Павла Галагана в Киеве. - К. : Тип. И.И. Чоколова, 1896. C. 1-23.
Наполеона Бонапарта початку XIX ст., були успішними на імперському поприщі: Дем'ян Васильович (1786-1859) і Олександр Васильович (адресат листа) були членами Державної Ради, Аркадій Васильович (1790-1878) - сенатором. У своїх біографічних нотатках небіж дав високу оцінку тому почуттю родинності, що об'єднувало цих людей: «Отличительная черта этого многочисленного семейства - была замечательная взаимная дружба [...] Несмотря на принадлежность свою к самому высокому светскому кругу, они сохранили между собою патриархальные отношения и самую нежную друг к другу привязанность...» ${ }^{7}$. Самого О.В. Кочубея у тому ж тексті Г.П. Галаган характеризує як людину, для котрої «хлопоты о ближнем были как бы главною задачею жизни...» ${ }^{8}$. Вочевидь, саме ставлення до адресата зумовило відверту та щиру манеру написання листа.

Зазначимо також, що для публікації текст було узгоджено із правилами сучасного російського правопису, зокрема враховано вимоги написання граматичних форм слів, вживання великої/малої літер тощо (як-от: означення вищих осіб імперії, подані автором з великої літери, у тексті вжиті 3 малої літери).

Сподіваємось, що публікація цього документа започаткує традицію оприлюднення на сторінках часопису джерельних матеріалів з історії України, які ще не увійшли до широкого обігу.

\footnotetext{
7 Там само. - C. 22

8 Там само.
}

\section{ДЖЕРЕЛА}

1. [Галаган Г.П.] Род Галаганов // 25-летие Коллегии Павла Галагана в Киеве / под ред. А.И. Степовича. - К. : Тип. И.И. Чоколова, 1896. - С. 1-23.

2. Абросимова С.В. Епістолярні джерела в їх історичному побутуванні та дослідницькому ареалі / С.В. Абросимова // Дніпропетровський історико-археографічний збірник. - Дніпропетровськ, 2009. - Вип. 3. - С. 57-115.

3. Інститут рукопису Національної бібліотеки України імені В.І. Вернадського. - Ф. 179. Оп. 1. - Спр. 131. - 6 арк.

4. Литвинова Т.Ф. «Поміщицька правда»: дворянство Лівобережної України та селянське питання наприкінці XVIII - у першій половині XIX століття (ідеологічний аспект) / Т.Ф. Литвинова. Д. : Лipa, 2011. - 732 c.

5. Про київське життя 1849 р. [Подав А. Степович] // Україна. - 1925. - № 6. - С. 109-110.

6. Центральний державний історичний архів України, м. Київ. - Ф. 486. - Оп. 5. - Спр. 319. Арк. 86-88. 


\section{REFERENCES}

1. [Galagan G.P.] Rod Galaganov // 25-letie Kollegii Pavla Galagana v Kieve / pod red. A.I. Stepovicha. K. : Tip. I.I. Chokolova, 1896. - S. 1-23.

2. Abrosymova S.V. Epistoliarni dzherela $\mathrm{v}$ yikh istorychnomu pobutuvanni ta doslidnytskomu areali // Dnepropetrovskyi istoryko-arkheohrafichnyi zbirnyk. - Dnipropetrovsk, 2009. - Vyp. 3. - S. 57-115. 3. Instytut rukopysu Natsionalnoi biblioteky Ukrainy imeni V.I. Vernadskoho. - F. 179. - Op. 1. Spr. 131. - Ark. 1.

4. Lytvynova T.F. «Pomishchytska pravda»: dvorianstvo Livoberezhnoi Ukrainy ta selianske pytannia naprykintsi XVIII - u pershii polovyni XIX stolittia (ideolohichnyi aspekt). - D. : Lira, 2011. - $732 \mathrm{~s}$.

5. Pro kyivske zhyttia 1849 r. [Podav A. Stepovych] // Ukraina. - 1925. — № 6. - S. 109-110.

6. Tsentralnyi derzhavnyi istorychnyi arkhiv Ukrainy, m. Kyiv. - F. 486. - Op. 5. - Spr. 319. Ark. 86-88.

\section{Київ, 16 листопада 1857 p.}

Киев, 16 ноября 1857

Все это время не писал Вам, любезный дядюшка, и верьте мне, что сим более всего чувствовал недостаток беседы с Вами. Хотел было писать Вам о пребывании государя императора в Киеве, да хотел об этом поговорить подробно и потому отложил, и не исполнил. Скажу Вам, однако же, хотя бы в общих чертах впечатления, произведенные на меня и на других величайшим приездом. Государь был все время необыкновенно со всеми милостив. Я представился ему в числе прочих и потом, зная, что он будет только ночевать в Чернигове, я туда не поехал. А вышло, что имп[ераторские] вел[ичества] пробыли там почти два дня. Государь осматривал гимназию, остался очень доволен и спросил обо мне $\mathrm{e}^{\mathrm{i}}$ вспомнив, что видел меня в Киеве. Не знаю наверное, что ему на это отвечали.

Но возвратимся к Киеву. Как Вам уже известно, государь простил студентов и был очень со всеми ласков ${ }^{\text {ii }}$. Это произвело большой энтузиазм в молодых людях. Они его провожали с криками и целовали его карету. Кстати, об этом: странно, что во всех газетах напечатали об этом и весьма неверно. Неверности в подобном случае не должны бы быть пропускаемы. Ребиндеруіiі, например, дали чин, который он вовсе не получил. С поляками государь был очень любезен, и они от него совершенно в восторге; они говорят теперь, что самые даже закоренелые из них обезоружены добротою государя. Киевляне принимали их имп[ераторские] вел[ичества] как умели лучше, и во все время их пребывания Киев действительно имел самый праздничный вид. Народ везде бегал за экипажами имп[ераторских] вел[ичеств], кажется, с непритворною преданностью. Мне в особенности понравилась императрица. Я редко встречал столько достоинства, величия и, вместе с тем, скромности, соединенными в одном лице, так что я искал случая побольше на нее посмотреть. Бал, данный дворянством, был чрезвычайно богат; комнаты были великолепно убраны. Одних шелковых материй для убранства комнат употребили баснословное для Киева количество - 22 тысячи аршин. Но при всем этом беспорядок на бале и особенно во время ужина был самый страшный, так что августейшим гостям надобно было призвать на помощь много снисходительности, чтобы не дать заметить того, что сами видели. Императрица много бывала в церквах, в пещерах ниж[них], осмотрела древности, все замечательные виды, причем погода все время им благоприятствовала. Пребывание их величеств в Киеве не осталось бесполезно и для меня. Я был представлен кн. Долгоруковуі по по его собственному желанию, и мы поговорили с ним хоть немного о настоящем положении вопроса крестьянско-помещичьего. Я удерживался от всяких преувеличений и увлечений (спешу это упомянуть). Кн[язь] Долгоруков был очень со мною любезен и объявил мне, что он намерен мне иногда писать и задавать некоторые вопросы. Многие из высших наших чиновников истинно благонамеренны, но в отношении известного вопроса бродят во тьме, потому что у них недостает опоры на людей практических. Мы готовы бы были им служить для общей пользы и совершенно даже устраняя свою личность от всякой чести в этом деле. Стоит этим господам вызывать людей практических, и я Вас уверяю, да и Вы сами в этом убеждены, что дело пойдет лучше на лад. Когда приеду зимою в Петербург, то, руководясь Вашим советом, я намерен явиться к кн[язю] Долгорукову. Кн[язь] Лев Викторович ${ }^{\mathrm{V}}$ и Позен ${ }^{\mathrm{vi}}$ подавали записку, в которой изложили свои мысли; были там и вещи дельные, но я не мог подписать ее вместе с ними, потому что в главных основах не вполне был с ними согласен. 
Возвратясь к себе домой, я очень был занят хозяйскими делами и переменою двух управляющих. Сахарный завод мой наконец пошел 26 октября ${ }^{\mathrm{vii}}$. Не знаю, как Бог даст, и кажется, что сей раз он устроен хорошо. Из Сокиринец ${ }^{\mathrm{viii}}$ мы выехали 29 и целую неделю прожили в Мостыще $\mathrm{e}^{\mathrm{ix}}$, где при благоприятной погоде я мог заняться делом. Приехавши сюда, я еще не застал высланного Вами вина, которое прибыло благополучно только третьего дня; но накладной при нем нет, вероятно, получу по почте.

18 ноября. Не окончил Вам письма третьего дня, потому что только завтра утром идет почта, а между тем вчера получил любезное письмо Ваше и вместе с ним накладную вина. Премного благодарю Вас, любезный дяденька, за Ваше одолжение. Деньги будут высланы вскорости, а письмо Ваше так долго шло потому, что Киевский почтамт отправил его в Прилуку, и оттуда опять по почте пришло оно сюда, а Вы знаете, как ходят у нас почты.

Меринг и также ее невестки ${ }^{\mathrm{x}}$ приносят Вам глубочайшую благодарность за участие Ваше в деле. Оно для г. Меринг решительно более чем полезно и даже спасительно, потому что поверенный ее Давиденко человек молодой, самонадеянный и при этом весьма требователен. При Вашем участии он побоится ее обидеть.

Рад сердечно, что Вы довольны теперешним состоянием Вашего здоровья. Молю Бога, чтобы оно продолжало Вам хорошо служить, и чтобы я застал Вас в Петербурге так, как расстался с Вами в Кунашевке $\mathrm{x}^{\mathrm{xi}}$. Мы оба обнимаем Вас от всей души. Крестник Ваш, слава Богу, растет благополучно хіi и вспоминает о своем дедушке, но еще более о кунашевском мосте, который часто строит чуть не через целую комнату. Прошу передать мой поклон дядюшкам и добрейшей тетушкехіiі.

Душевно Вам преданный и глубоко Вас уважающий племянник

Г. Галаган.

ІР НБУВ. - Ф. ІІІ. - On. 1. - Спр. 11 092. - 4 арк.

Друкується вперше.

\section{KOMEHTAPI}

і у 1853-1859 pр. Г.П. Галаган був почесним попечителем Чернігівської губерніальної гімназії.

ii Детально подробиці конфлікту студентів Київського університету з владою в 1857 р. дивіться у публікації: Отрывки из записок Автонома Акимовича Солтановского // Киевская старина. - 1892. - № 9. - С. 401. Цю інформацію люб'язно надано Є.А. Ковальовим.

iii Микола Романович Ребіндер (1813(?)-1865), дійсний статський радник, попечитель Київського навчального округу в $1856-1858$ рр., близький знайомий Г.П. Галагана.

iv Князь Василь Андрійович Долгоруков (1804-1868), генерал від кавалерії, генерал-ад’ютант, головний начальник III відділення Власної Його Імператорської Величності канцелярії.

v Лев Вікторович Кочубей (1810-1890), дійсний статський радник, полтавський губернський предводитель дворянства у 1853-1859рр. Одружений зі своєю родичкою Єлизаветою Василівною Кочубей, сестрою К.В. Галаган.

vi Михайло Павлович Позен (1798-1871), таємний радник, управляючий військово-похідною канцелярією Його Імператорської Величності, управляючий VI тимчасовим відділенням Власної Його Імператорської Величності канцелярії, яке опікувалося російськими володіннями у Закавказзі. Голова Полтавського комітету з покращення побуту поміщицьких селян.

vii Цукровий завод при маєтку в селі Ічня Борзнянського повіту Чернігівської губернії (зараз - районне місто Чернігівської області), власності Г.П. Галагана.

viii Сокиринці - маєток Галаганів у Прилуцькому повіті Полтавської губернії (зараз - Срібнянський район Чернігівської області), розбудований на околиці однойменного села на землях, отриманих у власність Гнатом (Ігнатом) Галаганом (?-1745) за гетьманським універсалом 1716 р.

ix Мостище - село Козелецького повіту Чернігівської губернії (зараз - Козелецького району Чернігівської області), де розташовувався маєток, що був успадкований родиною Галаганів від Дараганів (у їхній власності був 3 1750-х рp.)

x Йдеться, імовірно, про родичів Федора Федоровича (Фрідріха Фрідріховича) Мерінга (1822-1887) - лікаря, професора Університету св. Володимира у Києві, близького знайомого Галаганів.

xi Село Кунашівка (Конашівка) Борзнянського повіту Чернігівської губернії, один з маєтків Кочубеїв, в зазначений час був у власності О.В. Кочубея, на початку XX ст. належав його внучатому племіннику М.М. Кочубею.

xii Син Г.П. та К.В. Галаганів - Павло Григорович Галаган (1853-1869).

хіiі Йдеться про братів Дем’яна, Олександра та Аркадія Кочубеїв і їхню сестру Олену Василівну Маюрову (Майорову, 1793-1863), уроджену Кочубей. 
Марина Будзар

ИСТОРИЯ КИЕВА В ЕGО-ДОКУМЕНТАХ:

ПИСЬМО Г.П. ГАЛАГАНА К А.В. КОЧУБЕЮ 1857 г.

В статье приводится письмо Г.П. Галагана к дяде его жены А.В. Кочубею, в котором описан приезд в Киев Александра // в 1857 г.

Ключевые слова: Григорий Павлович Галаган, Александр Васильевич Кочубей, Киев, 1857 г.

\section{Maryna Budzar \\ KYIV HISTORY IN EGO-DOCUMENTS: HRYHORII GALAGAN'S LETTER TO OLEKSANDR KOCHUBEY, 1857}

The use of the epistolary heritage is one of the main requirements of the researchers who study Ukrainian cities. An important task is to reconstruct the history of Kyiv through the impressions of its inhabitants. Such a task is realized in the article, which is the publication of one of the letters of Hryhorii Pavlovych Galagan, the great landlord, influential public and cultural figure of the middle and second half of the $19^{\text {th }}$ century, to his wife's uncle, Oleksandr Vasyliovych Kochubey, the representative of the higher echelons of the imperial elite, a member of the State Council of Russian Empire. The document is a significant source. Apart the main theme of the letter - the visit of Emperor Alexander II to Kyiv in autumn of 1857, here is highlighted a number of socio-political and private-family issues. The publication of the document is important for the study of the Ukrainian elite of the $19^{\text {th }}$ century in multidimensional manifestations of social and everyday life.

Key words: Hryhorii Pavlovych Galagan, Oleksandr Vasyliovych Kochubey, Emperor Alexander II, Kyiv.

Дата надходження статmі до редакціі: 11.05.2017 p. 